\title{
Legal regulations of restrictions of air pollution made by non-road mobile machinery-the case study for Europe: a review
}

\author{
Konrad J. Waluś ${ }^{1} \cdot$ Łukasz Warguła $^{1} \cdot$ Piotr Krawiec $^{1} \cdot$ Jarosław M. Adamiec $^{1}$
}

Received: 6 June 2017 / Accepted: 27 November 2017 / Published online: 13 December 2017

(C) The Author(s) 2017. This article is an open access publication

\begin{abstract}
The high awareness of intensification and frequency of smog phenomenon all over the world in XXI age makes for detailed analyses of the reasons of its formation and prevention. The governments of the developed countries and conscious of real hazards, including many European countries, aim to restrict the emission of harmful gases. In literature, we can find the discussions on the influence of this phenomenon on the health and life of inhabitants of contaminated areas. Some elaborations of prognostic models, descriptions of pollution sources, the manner of their restriction, and the analysis of causal-consecutive correlation are also popular. The influence of pollutions resulting from the operation of vehicles, planes, and the industry are well described. However, every machine and device which is driven with a combustion engine has the effect on the general level of anthropogenic pollutions. These drives are subject of different regulations limiting their emission for service conditions and applications. One of the groups of such machines described in European and American regulations is non-road mobile machinery. The aim of this paper is the presentation of the problem of weak analysis and application of engineering and technological tools for machinery drive emission, despite of many publications on hazards and problems of emission. These machines have the influence on both the increase of global contamination and the machine users. The regulations of the European Union take into consideration the generated hazards and restrict the emission of machine exhaust gases by approval tests - these regulations are continually improved, and the effects of these works are new emission limits in 2019. However, these activities seem to be liberal as opposed to limits of the emission for passenger and goods vehicles where the technological development of the construction is greater and the regulations are the most rigorous. During the analysis of the development of non-road mobile machinery in the correlation with automotive vehicles, we can indicate engineering and technological solutions which are limiting the emission of non-road mobile machinery, but which are not applied. Due to liberal regulations for this group of machinery, the producers do not apply innovative solutions which can be found in road vehicles. The paper presents the synthetic review of existing EU regulations concerning limits of the emission of harmful exhaust gases which are generated by spark-ignition combustion engines of non-road mobile machinery. The authors show the divergences between the limits of the emission of harmful exhaust gases generated by road vehicles and non-road mobile machinery (boats and railway engines are not taken into account). The authors present the directions of the development of the combustion process control and systems limiting the emission of harmful exhaust gases. High innovative automotive industry was indicated as the direction of the development for limiting the influence of the emission on the environment by non-road mobile machinery.
\end{abstract}

Responsible editor: Philippe Garrigues

Konrad J. Waluś

konrad.walus@put.poznan.pl

Łukasz Warguła

lukasz.wargula@put.poznan.pl

Piotr Krawiec

piotr.krawiec@put.poznan.pl

Jarosław M. Adamiec

jaroslaw.adamiec@put.poznan.pl

1 Faculty of Machines and Transport, Poznan University of Technology, Poznan, Poland
Keywords Air pollution - Exhaust emissions - European homologation directives - Non-road mobile machinery · Combustion engine

\section{Introduction}

During last decades, the emission of air pollution in Europe was considerably decreased (Lackovičová et al. 2013; Lacressonnière et al. 2017). Concentrations of air pollution are still high, and we still have problems with the air quality (Guerreiro et al. 2014; Nieuwenhuijsen 2016; Squizzato et al. 2017). Considerable part of European population lives in areas 
(especially in large cities) where the standards of air quality are broken (Pascal et al. 2013; Beelen et al. 2014; Battista et al. 2016; Rodriguez et al. 2016). This situation is one of the reasons of dysphoria (Zijlema et al. 2016; Le Boennec and Salladarré 2017), loss of physical-motion capacity (Lichter et al. 2017), loss of health (Docker 2001; Oberdorster 2001; Vedal S 2002; Pereira Filho et al., 2008; Yang and Omaye 2009, Rückerl et al. 2011; Byeong-Jae et al. 2014; Sack and Kaufman 2016; Sanidas et al. 2017), and premature death (Hoek et al. 2013; WHO Regional Office for Europe and OECD 2015; Badyda et al. 2017). The sources of air pollution can be divided into natural (Liora et al. 2016) and anthropogenic ones (Avila and Alarcon 2003). Natural sources of air pollution are generated during process of e.g., chemical weathering of rocks, fire of forests and steppes, volcanic eruptions, and generation of atmospheric aerosols. Among the anthropogenic sources, we can specify ones which are generated by human activity e.g., biomass production (Beltman et al. 2013; Cordell et al. 2016), using of road vehicles (Klæboe et al. 2008; Hulskotte et al. 2014), air transport (Masiol and Harrison 2014; Koudis et al. 2017; Y1lmaz 2017), sea transport (Bencs et al. 2017), mining and extractive industry (Fugiel et al. 2017), households consumption (Büchs and Schnepf 2013; Pyka and Wierzchowski 2016), and heat and power generating plants (Bieda 2011; Dulcea and Ionel 2015). More and more higher level of air pollution in conurbations leads to the implementation of legal restrictions of the emission of harmful exhaust gases in all industry branches (Szczepanek 2009; Jaś-Nowopolska 2014)_also in branch of propulsions which are applied in non-road mobile machinery. The definition of non-road mobile machinery according to the European Union directive on the emission of harmful exhaust gases is the following (Journal of Laws from 2014, No. 0 , item 588):

"non-road mobile machinery shall mean transportable industrial equipment or vehicle with or without body work, not intended for the use of passenger or goods to transport on the road, or any mobile machinery intended and adopted to move on the road or rails in which an internal combustion engine is installed i.e.,:

- compression ignition engine with the net power output equal or higher than $19 \mathrm{~kW}$, but not higher than $560 \mathrm{~kW}$, which operates rather with a constant rotational speed and works on the basis of self-ignition principle, or - compression ignition engine with the net power output equal or higher than $19 \mathrm{~kW}$, but not higher than $560 \mathrm{~kW}$, which operates with a constant rotational speed and works on the basis of self-ignition principle, or

- spark ignition engine with the net power output equal or lower than $19 \mathrm{~kW}$ which works on the basis of spark ignition principle and it is supplied with petrol, or
- engine designed for driving the rail cars i.e. mobile rail vehicles which are applied to transport cargo or passengers, or

- engine designed for driving the locomotives i.e. mobile rail vehicles which are applied to move freight wagons or carriages, but without locomotive service staff, or other equipment."

Examples of non-road mobile machinery with spark ignition engine are the following: grass mowers, chainsaws, generators, water pumps, hedge trimmers, twig choppers, snow removal machines, and devices applied in forestry (Journal of Laws from 2014, No. 0, item 588). The main incentive for elaboration of innovative constructions which restrict the emission of toxic compounds in exhaust gases is the implementation of more and more rigorous homologation rules. Liberal rules of the emission of toxic compounds in exhaust gases for non-road mobile machinery lead to the common application of fuel supply systems with carburetor. On the basis of the review of present engines for non-road mobile machinery, which was performed on January 2017, one can conclude that only $11 \%$ of spark ignition engines are equipped with the electronic injection system. The advantages of the application of the electronic injection-ignition systems are the following: lower fuel consumption, lower content of toxic compounds in exhaust gases, higher efficiency of combustion process, power and torque increase, improvement of reaction dynamics on the variation of operating conditions, reduction of number of control-service activity, general reduction of the level of impact on the environment due to self-diagnosis of system, the ability to work in emergency mode and indicator of system failure MIL (malfunction indicator lamp), facilitation of system diagnosis by the use of diagnostic functionswork parameters monitoring and failure code recording (Warguła and Waluś 2014; Waluś et al. 2017). Among the main manufacturers of combustion engines with spark ignition for non-road mobile machinery who apply the electronic injection-ignition systems EFI (electronic fuel injection), we can enumerate the following ones: Kohler Engines, Briggs \& Stratton, Honda, Kawasaki, Subaru Robin, and Yamaha. Additionally, ECOTRONS company produces modification kits for such type of engines which allow to implement the electronic injection-ignition system. The applied systems are different and deviate from the standards of present produced passengers vehicles which are pioneers in the branch of combustion engine development. The solutions used in EFI systems for combustion engines of non-road mobile machinery had been also commonly applied in automotive vehicles. These ones were displaced by newer solutions or were additionally equipped with the innovative systems. In case of circuits, systems, and subassemblies, which are characteristic for present construction elements (reducing the emission of harmful gases) of the injection-ignition systems in combustion 
engines with spark ignition for mobile machinery propulsions, the following elements are not applied: resistance sensor of oxygen content in exhaust gases (broadband Lambda sensor) (Ivers-Tiffée et al. 2001; Riegel et al. 2002; Ramamoorthy et al. 2003; Wales et al. 2015), a few oxygen detectors in exhaust gases (Twigg 2006), nitrogen oxides detectors in exhaust gases (Ménil et al. 2000; Moos 2005), direct injection to combustion chamber (Badami et al. 1999; Zhao et al. 1999), absorption of fuel vaporous (Jentz et al. 2014), three-function catalytic reactor (Heck and Farrauto 2001; Twigg 2007), measurement of air mass flow with wire anemometer HLM (Hitzdraht luftmassenmesser) or plate anemometer HFM (Heißfilmluftmassenmesser), system of additional air blow to exhaust manifold (Sathish and Loganathan 2017), exhaust gas recirculation system (Yu et al. 2013; Ueda 2015), systems with the dynamic supercharging phenomenonsupercharging with the use of turbocompressor, mechanical compressor or Comprex compressor, start-stop system, and variable valve timing.

The emission restriction is also necessary due to its direct influence on humans' health who live not only in Europe (Zeng et al. 2016; Tang et al. 2017).

There are conducted some research on the emission level generated by combustion engines of non-road mobile machinery and its influence on the environment and operators (Czerwinski et al., 2014; Lijewski 2015; Merkisz et al. 2016; Liu et al. 2016; Dimou et al. 2017; Hooper et al. 2017). The research were performed in China in year 2006 (Zhang et al. 2006), and these ones showed that the emission of PM2.5 from road vehicles was equal to 123,000 tons, and from the propulsions of non-road machinery was equal to 38,000 tons (Wang et al. 2016). The results of research conducted in the USA in year 2006 showed that the operators of machinery with such type of combustion engines can be endangered to the increased level of $\mathrm{CO}$ and PM2.5 which can be higher about two orders of magnitude (Baldauf et al. 2006). It means that the emission generated by such type of machinery cannot be ignored, because it is a part of global contamination of the world, but it is also a significant local contamination of the workstation and local health and life hazard.

In literature, one can find the subject matter of legal regulations on the emission of air pollutions generated in Europe. We can indicate the following directions of legal and political aspirations to the reduction of the emission of toxic exhaust gases from combustion engines:

- rigorous emission standards for the stage of certification, operation, and production;

- investments into the technological development of constructions which are using products made of petroleum and constructions which are independent from the petroleum;

- reforms of fuel tax.
Among all the calculations of the generated emission in Europe or in the selected European areas and all the determinations of the results of the introduced solutions for emission limits, the scientists, whose papers are described below, state that the effects of introduced solutions are ambiguous or very complicated. Bagayev and Lochard's paper from the year 2017 concerning the adjustment of air pollutions generated by the industry in the European Union, indicates that the developed countries of EU implement more rigorous emission standards of air pollutions than the developing countries of Europe or Asia, because these ones import from those ones more products which are intensively polluting the air (Bagayev and Lochard 2017). In 2014, Rafaj showed that the limitation strategy of the emission of air pollutions TSAP (Thematic Strategy on Air Pollution), which was taken by the European Committee in 2005, will not be fulfilled without any additional activities (Rafaj et al. 2014). In 2017, Lacressonničre et al. indicated that the annual value of PM10 can be reduced about ca. $1.8-2.9 \mu \mathrm{g} / \mathrm{m}^{3}$ in compliance with the present legal scenario-especially for the countries of Benelux (Lacressonnière et al., 2017). When maximum technological possibilities of the emission reduction will be implemented, then the annual value of PM10 can reach the level of $1.4-1.9 \mu \mathrm{g} / \mathrm{m}^{3}$ (Lacressonnière et al. 2017). The global and overall determination of the emission level of pollutions for specific geographic areas is complicated and multidimensional - this issue is discussed by e.g., Ederington, Levinson and Taylor, Brunel and Levinson (Ederington et al. 2005; Levinson and Taylor 2008; Brunel and Levinson, 2016). Completely different manners limiting the emission of exhaust gases in Europe are tax reforms for the purpose of the limitation of harmful pollutions of air and the emission of the carbon dioxide in the road transport. The results of such political interventions were described by Zimmer and Koch in 2017-they indicated that the fuel consumption is elastic, and the results of reforms have significantly allowed to achieve the aims of the EU within the range of policy of the counteractions to climatic changes for the year 2020 (Zimmer and Koch 2017). The existing policy in Europe within the range of the emission limitation of the air pollution is not coherent, but the directions of the emission limitation with the technology, rigorous regulations of approval or fuel tax regulations give the measurable advantages in the form of the emission reduction (Creutzig et al. 2011). The investigations showed a strong synergy between the climatic policy and the policy within the range of air pollutions (Bollen and Brink 2014; Nam et al. 2014). The motor market for the purpose of supporting the reduction of climate changes decreases its dependence from the petroleum. In EU, the works on standards of the fuel efficiency has begun from the voluntary agreement which established the general aim to $140 \mathrm{gCO}_{2} / \mathrm{km}$ for $\mathrm{EU}$ and it must be reached by European, Japanese and Korean carmakers. In 2009, it was indicated that until the year 2015, this 
value has to be equal $130 \mathrm{~g} \mathrm{CO}_{2} / \mathrm{km}$ (Creutzig et al. 2011). The reduction about $10 \mathrm{~g} \mathrm{CO}_{2} / \mathrm{km}$ can be obtained by implementing the actions such as efficient tires, air conditioning, tire pressure monitoring, and gear shift indicators (Regulation (EC), 2009). Long-term aim for the year 2020 is equal $95 \mathrm{CO}_{2} / \mathrm{km}$ (Creutzig et al. 2011). The authors of the above papers confirm Bagayev and Lochard's conclusion from 2017 that the influence of regulations of environment protection and economy on the air quality cannot be unequivocally determined (Bagayev and Lochard 2017). The presented paper indicates that one of solutions for the human health protection can be the limitation of the emission from engines of non-road mobile machinery. In opposite to global regulations connected with the emission of devices, the homologation restrictions force the producers to make environmentfriendly devices and displace devices and machines made in older technology. The obtained effects of rigorous emission standards have the unequivocal influence on the emission reduction.

The paper presents the European homologation rules for combustion engines with spark ignition for non-road mobile machinery. The rules for this type of machinery were referred to the homologation rules of the other group of combustion engines for road vehicles mainly where the allowable limits of the emission are more rigorous. This analysis does not take into consideration the combustion engines with compression ignition and the engines for boats and locomotives. The aim of this paper is to present the significant differences between the rules for combustion engines of non-road mobile machinery and automotive vehicles. The allowable European limits for emission of toxic compounds in exhaust gases - nowadays and after the implementation of the directive 2016/1628/EU in year 2019-are very liberal. It allows the manufacturers to sell the constructions with old technologies. This situation additionally does not force the manufacturers to invest in innovative constructional solutions. The present development of control technology of combustion processes and limiting systems of the emission of toxic compounds in exhaust gases which are applied in automotive industry allow to restrict considerably the influence of this type of propulsions on the environment. The automotive industry shows the direction of the propulsions development for non-road mobile machinery which allows to protect the environment in the whole world.

\section{The European homologation rules}

In Europe, first regulations for non-road vehicles were presented in December 1997 (Directive, 1997/68/EC). The regulations for limiting the emission level of toxic compounds were implemented in two stages (Stage I and Stage II) - first stage was implemented in 1999, and second one was implemented in years 2001-2004 for different engine powers. First
European Union standards concerning the emission for combustion engines with spark ignition below $19 \mathrm{~kW}$ applied in non-road mobile machinery were implemented in 2002.

Stages I and II were implemented by the Directive, 2002a/ 88/EC which has replaced the Directive, 1997/68/EC. The directive from year 2002 has implemented the standards for the emission of spark ignition engines with small power below $19 \mathrm{~kW}$ for non-road mobile machinery. It has also implemented the division of engines into the following classes: engines for hand-held machinery- $\mathrm{H}$, and engines for non-hand-held machinery- $\mathrm{N}$ (Table 1).

Emission limits for Stage I are given in Table 2, and for Stage II are given in Table 3. These standards are applied for spark ignition engines with a net power below $19 \mathrm{~kW}$ (class S). Irrespective of the definition of hand-held two stroke engine, in Stage I and II, the engines for mechanical snow removal machines must satisfy only the emission limits for SH:1, SH:2, or SH:3 (DieselNet- Emission Standards, 2017).

Next legal document concerning the emission from nonroad vehicles is the Directive 2004/26/EC from the year 2004. On the basis of this document, next emission limits of toxic compounds were implemented in two stages: III and IV (Stage III and Stage IV) - it was distributed in years 2006-2014. Additionally, Stage III was divided into two sub-stages: IIIA and IIIB. Stage IIIB incorporates very restrictive limits for the emission of nitrogen oxides $\left(\mathrm{NO}_{\mathrm{x}}\right)$ and particulate solids $(\mathrm{PM})$ - the emission of particulate solids was reduced about 90\% in relation to Stage II. In 2015, next document was elaborated and implemented, i.e., the Directive 2005/13/EC concerning the engines of vehicles applied in agriculture and forestry. In 2010, two additional directives were implemented: the Directive, 2010a/26/UE - it incorporates further technical details on testing and homologation of engines from Stage IIIB and IV; the Directive, 2010b/22/UE - it changes the earlier regulations for vehicles which are applied in agriculture and forestry. The regulations described in Stages III and IV do
Table 1 Spark ignition engines - ranked to $\mathrm{S}$ class (engines with a net of Laws from 2014, No. 0, item 588) power $\leq 19 \mathrm{~kW}$ ) (Journal

\begin{tabular}{ll}
\hline Class & Displacement $\left(\mathrm{cm}^{3}\right)$ \\
\hline Hand-held engines & \\
SH:1 & $<20$ \\
SH:2 & $\geq 20$ \\
& $<50$ \\
SH:3 & $\geq 50$ \\
Non-hand-held engines & \\
SN:1 & $\geq 66$ \\
SN:2 & $\geq 66$ \\
& $<100$ \\
SN:3 & $\geq 100$ \\
& $<225$ \\
SN:4 & $\geq 225$ \\
\hline
\end{tabular}


Table 2 Emission limits of toxic compounds in exhaust gases - Stage I in Europe for spark ignition engines with the power below $19 \mathrm{~kW}$ of nonroad mobile machinery and date of implementation (DieselNet- Emission
Standards, 2017; Directive, 1997/68/WE; Directive 2001/63/WE; Directive, 2002a/88 /WE; Directive 2004/26/WE; Directive, 2010a/26/ UE; Directive 2011/88/UE; Directive 2012/46/UE)

\begin{tabular}{|c|c|c|c|c|c|}
\hline Class & Date & Carbon monoxide (CO) & Hydrocarbons (HC) & Nitrogen oxides $\left(\mathrm{NO}_{\mathrm{x}}\right)$ & $\begin{array}{l}\text { Sum of hydrocarbons } \\
\text { and oxides of nitrogen } \\
\left(\mathrm{HC}+\mathrm{NO}_{\mathrm{x}}\right)\end{array}$ \\
\hline
\end{tabular}

$(\mathrm{g} / \mathrm{kWh})$

Hand-held engines

\begin{tabular}{|c|c|c|c|}
\hline SH:1 & 2004 & 805 & 295 \\
\hline SH:2 & & 805 & 241 \\
\hline
\end{tabular}

Non-hand-held engines

\begin{tabular}{|c|c|c|c|c|c|}
\hline SN:1 & 2004 & 519 & - & - & 50 \\
\hline $\mathrm{SN}: 2$ & & 519 & - & - & 40 \\
\hline $\mathrm{SN}: 3$ & & 519 & - & - & 16. \\
\hline $\mathrm{SN}: 4$ & & 519 & - & - & \\
\hline
\end{tabular}

not concern to spark ignition combustion engines with net power below $19 \mathrm{~kW}$.

In 2016, the standards of Stage V were accepted - these will be obligatory from 2019 - the emission regulations were restricted and classes of spark ignition engines were enlarged. Stage V of the emission regulations intensifies the emission standards for existing engine classes and enlarges the number of engine classes for the engines which have not been taken into consideration in earlier regulations. We can distinguish category NRSh - the spark ignition engines with the power below $19 \mathrm{~kW}$ used in hand-held applications only (Table 4). We can also distinguish category NRS - the spark ignition engines with the power below $56 \mathrm{~kW}$ which have not been taken into consideration of category NRSh (Table 5). We can also distinguish category SMB-for spark ignition engines

Table 3 Emission limits of toxic compounds in exhaust gases - Stage II in Europe for spark ignition engines with the power below $19 \mathrm{~kW}$ of nonroad mobile machinery and date of implementation (DieselNet- Emission

\begin{tabular}{|c|c|c|c|c|c|}
\hline Class & Date & Carbon monoxide (CO) & Hydrocarbons (HC) & Nitrogen oxides $\left(\mathrm{NO}_{\mathrm{x}}\right)$ & $\begin{array}{l}\text { Sum of hydrocarbons } \\
\text { and oxides of nitrogen } \\
\left(\mathrm{HC}+\mathrm{NO}_{\mathrm{x}}\right)^{*}\end{array}$ \\
\hline
\end{tabular}

$(\mathrm{g} / \mathrm{kWh})$

Hand-held engines

\begin{tabular}{|c|c|c|c|c|c|}
\hline SH: 1 & 2007 & 805 & - & - & 50 \\
\hline SH:2 & & 805 & - & - & 50 \\
\hline SH:3 & 2008 & 603 & - & - & 72 \\
\hline \multicolumn{6}{|c|}{ Non-hand-held engines } \\
\hline $\mathrm{SN}: 1$ & 2004 & 610 & - & - & 50 \\
\hline $\mathrm{SN}: 2$ & & 610 & - & - & 40 \\
\hline $\mathrm{SN}: 3$ & 2007 & 610 & - & - & 16.1 \\
\hline $\mathrm{SN}: 4$ & 2006 & 610 & - & - & 12.1 \\
\hline
\end{tabular}

*Additionally, NOx for all engine classes cannot exceed $10 \mathrm{~g} / \mathrm{kWh}$ applied in snowmobiles, and category ATS - for spark ignition engines applied in "all terrain" and "side-by-side" vehicles. The engines with the power higher than $56 \mathrm{~kW}$ must satisfy the emission standards for engines from category NRE. This category includes all types of engines with the power higher than $56 \mathrm{~kW}$ both for spark and compression ignition (Regulation 2016/1628/UE). The emission limits of Stage $\mathrm{V}$ for spark ignition engines with the power below $19 \mathrm{~kW}$ applied in hand-held machinery and spark ignition engines with the power up to $56 \mathrm{~kW}$ applied in non-handheld machinery are given in Table 6. Emission limits of toxic compounds in exhaust gases of Stage V in Europe for spark ignition engines applied in propulsions of snowmobiles (SMB-v-1) and "all terrain" and "side-by-side" vehicles (ATS-V-1) are presented in Table 7. Emission in Stage V is

Standards, 2017; Directive, 199768/WE; Directive 2001/63/WE; Directive, 2002b/88 /WE; Directive 2004/26/WE; Directive, 2010b/26/ UE; Directive 2011/88/UE; Directive 2012/46/UE) and oxides of nitrogen 
Table 4 Division of spark ignition engines of class $\mathrm{S}$ with the net power $\leq 19 \mathrm{~kW}$ according to Stage $\mathrm{V}$, applied in hand-held machinery (DieselNet- Emission Standards, 2017; Regulation 2016/1628/UE)

\begin{tabular}{ll}
\hline Category & Displacement $\left(\mathrm{cm}^{3}\right)$ \\
\hline Hand-held engines & \\
NRSh-v-1a & $<50$ \\
NRSh-v-1b & $\geq 50$ \\
\hline
\end{tabular}

measured in different test cycles depending on the machinery service conditions (e.g., DieselNet- Emission Standards, 2017; Regulation 2016/1628/UE).

In next years, the legislation concerning Stage V obligates the European Commission to present two reports on further regulations of the exhaust gases emission. First report must be ready until the end of year 2018, and it will refer to estimation of possibilities to take some actions connected with the installation of additional devices for emission control in existing (used) non-road vehicles. Second report must be ready until the end of year 2020, and it will refer to estimation of further potential reduction of contamination emission and identification of potentially existing types of contaminations which are not incorporated in regulations of Stage V (DieselNetEmission Standards, 2017).

Apart from regulations in the European Union, some additional regulations of the emission for non-road vehicles are implemented by some countries. The example of such activity is the establishment of low-emission zone LEZ - this is an area where operation of vehicles which contaminate the environment is restricted, in this area the following types of vehicles can be used: alternative fuel vehicles, hybrid electric vehicles, or zero-emission vehicles such as all-electric vehicles. In 2015, over 200 zones of such type were established in Europe (Cruz and Montenon 2016). In 1996, the largest cities in Sweden implemented the program Environmental Zonesthe main aim of this program was the improvement of the air quality by the traffic restriction of HDV (Heavy-Duty
Table 6 Emission limits of toxic compounds in exhaust gases according to Stage $\mathrm{V}$ in Europe for spark ignition engines with the power below $19 \mathrm{~kW}$ applied in hand-held mobile machinery and with the power up to $56 \mathrm{~kW}$ applied in non-hand-held mobile machinery and date of implementation (DieselNet- Emission Standards, 2017; Regulation 2016/1628/UE)

\begin{tabular}{llll}
\hline Category & Date & $\begin{array}{l}\text { Carbon monoxide } \\
(\mathrm{CO})\end{array}$ & $\begin{array}{l}\text { Sum of hydrocarbons } \\
\text { and oxides of nitrogen } \\
\left(\mathrm{HC}+\mathrm{NO}_{\mathrm{x}}\right)^{*}\end{array}$ \\
\hline
\end{tabular}

$(\mathrm{g} / \mathrm{kWh})$

Hand-held engines

$\begin{array}{llll}\text { NRSh-v-1a 2019 } & 805 & 50 \\ \text { NRSh-v-1b } & 603 & 72 \\ \text { Non-hand-held engines } & & \\ \text { NRS-vr/vi-1a 2019 } & 610 & 10 \\ \text { NRS-vr/vi-1b } & 610 & 8 \\ \text { NRS-v-2a } & 610 & 8 \\ \text { NRS-v-2b } & 4.40^{*} & 2.70^{*} \\ \text { NRS-v-3 } & & 4.40^{*} & 2.70^{*}\end{array}$

*or any combination of the values which satisfy the equation: $(\mathrm{HC}+$ $\left.\mathrm{NO}_{\mathrm{x}}\right) \cdot \mathrm{CO}^{0.784} \leq 8.57$, conditions: $\mathrm{CO} \leq 20.6 \mathrm{~g} / \mathrm{kWh}$ and $\left(\mathrm{HC}+\mathrm{NO}_{\mathrm{x}}\right) \leq$ $2.7 \mathrm{~g} / \mathrm{kWh}$

Vehicles) vehicles in city centers. In 1999, the similar program was implemented, and it referred to non-road vehicles. According to the accepted project, all engines which do not satisfy the European or American standards (Stage I/Tier 1) must be equipped with a catalytic reactor when these ones achieve the age of 8 , and in some cases, these ones must be equipped with a filter of solid particulates DPF (diesel particulate filter) (Merkisz and Walasik 2006). In Switzerland, similarly as in Sweden, one of the main actions is the assembly of diesel particulate filters. Initially, since year 2000, the obligation of assembly of diesel particulate filters was implemented for building machinery applied in underground constructions (tunnels and parking places), and since 2002, for all machinery applied in large constructions (Merkisz and Walasik 2006).
Table 5 Division of spark ignition engines of class $\mathrm{S}$ with the net power $\leq 56 \mathrm{~kW}$ according to Stage V, applied in non-handheld machinery (DieselNetEmission Standards, 2017; Regulation 2016/1628/UE)

\begin{tabular}{llll}
\hline Category & Displacement $\left(\mathrm{cm}^{3}\right)$ & Power $(\mathrm{kW})$ & Speed operation (rpm) \\
\hline Non-hand-held engines & & & \\
NRSh-vr-1a & $\geq 80$ & $<19$ & Variable $\geq 3600 ;$ or constant \\
& $<225$ & & \\
NRSh-vr-1b & $\geq 255$ & & Variable $<3600$ \\
NRSh-vi-1a & $\geq 80$ & & \\
NRSh-vi-1b & $<225$ & & \\
NRS-v-2a & $\geq 255$ & $\leq 19$ & \\
& $\leq 1000$ & $>30$ & \\
NRS-v-2b & $>1000$ & $\leq 30$ & \\
NRS-v-3 & Any & $>56$ & \\
\hline
\end{tabular}


Table 7 Emission limits of toxic compounds in exhaust gases of Stage $\mathrm{V}$ in Europe for spark ignition engines applied in propulsions of snowmobiles (SMB-v-1) and "all terrain" vehicles (ATS-v-1) and data of categories implementation (DieselNet- Emission Standards, 2017; Regulation 2016/1628/UE)

Category Date Power Carbon monoxide (CO)

Sum of

hydrocarbons and oxides of nitrogen $\left(\mathrm{HC}+\mathrm{NO}_{\mathrm{x}}\right)$

\section{$(\mathrm{kW}) \quad(\mathrm{g} / \mathrm{kWh})$}

SMB-v-1 $2019>0 \quad 275$

ATS-v-1 $2019>0 \quad 400$

\section{The analysis of homologation research methods of the emission of non-road combustion engines with spark ignition}

Homologation tests of combustion engines applied for drives of non-road mobile machinery are obligatory in the European Union countries, and these tests are orientated on the emission of toxic compounds of exhaust gases. Standard ISO 8178, elaborated by the International Standard Organization (ISO), consists of the following 10 parts:

- part 1: Test-bed measurement systems of gaseous and particulate emissions (ISO 8178-1 2017)

- part 2: Measurement of gaseous and particulate exhaust emissions under field conditions (ISO 8178-2 2008)

- part 3: Definitions and methods of measurement of exhaust gas smoke under steady-state conditions (ISO 8178-3 1994)

- $\quad$ part 4: Steady-state and transient test cycles for different engine applications (ISO 8178-4 2017)

- $\quad$ part 5: Test fuels (ISO 8178-5 2015)

- $\quad$ part 6: Report of measuring results and test (ISO 8178-6 2000)

- $\quad$ part 7: Engine family determination (ISO 8178-7 2015)

Table 8 NRSC test cycles for engines of category NRSh, NRS, SMB, and ATS (Journal of Laws from 2014, No. 0 , item 588)

\begin{tabular}{ll}
\hline Category & NRSC \\
\hline NRSh-v-1a & G3 \\
NRSh-v-1b & \\
NRS-vi-1a & G1 \\
NRS-vi-1b & \\
NRS-vr-1a & G2 \\
NRS-vr-1b & \\
NRS-v-2a & \\
NRS-v-2b & C2 \\
NRS-v-3 & C2 \\
SMB-v-1 & H \\
ATS-v-1 & G1 \\
\hline
\end{tabular}

- $\quad$ Part 8: Engine group determination (ISO 8178-8 2015)

- part 9: Test cycles and test procedures for test bed measurement of exhaust gas smoke emissions from compression ignition engines operating under transient conditions (ISO 8178-9 2012)

- part 10: Test cycles and test procedures for field measurement of exhaust gas smoke emissions from compression ignition engines operating under transient conditions (ISO 8178-10 2002)

- part 11: Test-bed measurement of gaseous and particulate exhaust emissions from engines used in non-road mobile machinery under transient test conditions (Withdrawn in 2014.08.13) (ISO 8178-11 2006)

Test procedure can be done with two types of test cycles: NRSC - stationary cycle for non-road machinery (Non-Road Stationary Cycle), and NRTC — nonstationary cycle for nonroad machinery (Non-Road Transient Cycle). Additionally, depending on the application of the device, types of service conditions or group and series of engines, the tests are performed in defined test cycles which differ in service conditions and number of research phases. On the basis of conducted tests, one can calculate the mean emission of the individual toxic compounds of exhaust gases - depending on the application of the examined engine one can match characteristic contribution coefficients for every phase of the test. Table 8 presents types of test cycles for different category groups of engines, i.e., NRSh, NRS, SMB, and ATS.

Test cycle of non-road mobile machinery equipped with spark ignition engines with the net power not higher than $19 \mathrm{~kW}$ is done for defined test cycles and depends on the application of device and its service conditions. Type of driven machine determines the following measuring cycles of the engine which is connected with the brake:

- cycle D (it is identical with cycle D2 according to standard ISO 8168-4: 1996(E)): engines with a constant rotational speed and with different loads such as in power generators;

- cycle G1: it is applied to engines mounted in machines with different rotational speed which are not hold in hands;

- cycle G2: it is applied to engines with rated rotational speed which are not hold in hands;

- cycle G3: it is applied to engines mounted in machines which are hold in hands.

Exemplary test phases and weighting factors are presented in Table 9 where the rated rotational speed is equal to maximal one at full load - it is restricted with governor according to producer's data. The indicated intermediate rotational speed is equal to rotational speed of the engine when the following conditions are satisfied: 
Table 9 Test phases and weighting factors for test cycle D, G1, G2, G3 (Journal of Laws from 2014, No. 0, item 588)

\section{Cycle D}

\begin{tabular}{|c|c|c|c|c|c|c|c|c|c|c|c|}
\hline \multirow{2}{*}{\multicolumn{2}{|c|}{$\begin{array}{l}\text { Number of phase } 1 \\
\text { Rotational speed of engine }\end{array}$}} & 2 & 3 & 4 & 5 & \multirow{3}{*}{\multicolumn{3}{|c|}{ Intermediate rotational speed }} & \multirow{2}{*}{\multicolumn{3}{|c|}{ Rotational speed of idle running }} \\
\hline & & & \multicolumn{3}{|c|}{ Rated rotational speed } & & & & & & \\
\hline Load* $(\%)$ & 100 & 75 & 50 & 25 & 10 & & & & & & \\
\hline Weighting factor & 0.05 & 0.25 & 0.3 & 0.3 & 0.1 & & & & & & \\
\hline \multicolumn{12}{|l|}{ Cycle G1 } \\
\hline \multicolumn{3}{|l|}{ Number of phase } & & & & 1 & 2 & 3 & 4 & 5 & 6 \\
\hline \multicolumn{3}{|c|}{ Rotational speed of engine } & \multicolumn{3}{|c|}{ Rated rotational speed } & \multicolumn{3}{|c|}{ Intermediate rotational speed } & \multicolumn{3}{|c|}{ Rotational speed of idle running } \\
\hline \multicolumn{3}{|l|}{ Load $(\%)$} & & & & 100 & 75 & 50 & 25 & 10 & 0 \\
\hline \multicolumn{3}{|l|}{ Weighting factor } & & & & 0.09 & 0.2 & 0.29 & 0.3 & 0.07 & 0.05 \\
\hline \multicolumn{12}{|l|}{ Cycle G2 } \\
\hline Number of phase & 1 & 2 & 3 & 4 & 5 & & & & & & 6 \\
\hline \multicolumn{3}{|c|}{ Rotational speed of engine } & \multicolumn{3}{|c|}{ Rated rotational speed } & \multicolumn{3}{|c|}{ Intermediate rotational speed } & \multicolumn{3}{|c|}{ Rotational speed of idle running } \\
\hline Load $(\%)$ & 100 & 75 & 50 & 25 & 10 & & & & & & 0 \\
\hline Weighting factor & 0.09 & 0.2 & 0.29 & 0.3 & 0.07 & & & & & & 0.05 \\
\hline \multicolumn{12}{|l|}{ Cycle G3 } \\
\hline Number of phase & 1 & & & & & & & & & & 2 \\
\hline \multicolumn{3}{|c|}{ Rotational speed of engine } & \multicolumn{3}{|c|}{ Rated rotational speed } & \multicolumn{3}{|c|}{ Intermediate rotational speed } & Rota & speed o & unning \\
\hline Load $(\%)$ & 100 & & & & & & & & & & 0 \\
\hline Weighting factor & $0.85^{* *}$ & & & & & & & & & & $0.15 * *$ \\
\hline
\end{tabular}

*Load values are expressed as percentage values of torque which corresponds to the basic value of the power defined as the maximal power obtained during variable power sequence - it can be received during unlimited number of hours in the year between the defined service periods and for the given environmental conditions; maintenance is done according to producer's data

**For Stage I, the following values can be taken 0.90 and 0.10 instead of 0.85 and 0.15

- for the case of engines which work in range of rotational speed on the moment curve at full load, the intermediate rotational speed should be taken as declared rotational speed of maximal moment - if this moment exists between 60 and $75 \%$ of rated rotational speed,

- if the declared rotational speed of maximal moment is less than $60 \%$ of rated rotational speed, then intermediate rotational speed should be equal to $60 \%$ of rated rotational speed,

- if the declared rotational speed of maximal moment is higher than $75 \%$ of rated rotational speed, then intermediate rotational speed should be equal to $75 \%$ of rated rotational speed,

- for the case of engines which are assigned to tests according to cycle G1, the rotational speed should be equal to $85 \%$ of rated rotational speed.

The selection of a proper test cycle, when we know the last application of engine model, can be done on the basis of the below presented examples. If the last application of engine is unknown, then test cycle should be done on the basis of technical data of the engine. Typical examples of test cycles for the following applications:
- Cycle D: generating sets with intermittent load including generating sets on board ships and trains (not for propulsion), refrigerating units, welding sets, gas compressors.

- Cycle G1: front or rear engines riding lawn mowers, golf carts, lawn sweepers, pedestrian-controlled rotary, or cylinder lawn mowers, snow-removal equipment, waste disposers.

- Cycle G2: portable generators, pumps, welders, and air compressors may also include lawn and garden equipment, which operate at engine rated speed.

- Cycle G3: blowers, chain saws, hedge trimmers, portable saw mills, rotary tillers, sprayers, string trimmers, vacuum equipment.

The valid homologation regulations of combustion engines of non-road mobile machinery during research tests allow to represent the real service conditions of the engines. The investigations performed in 2017 show that the measured emission of $\mathrm{HC}$ and $\mathrm{CO}$ generated (in real operation conditions) by selected non-road mobile machinery equipped with spark ignition engines are higher than the allowable values. This fact results from different service conditions of engine than defined ones by standards of homologation tests. Additionally, these investigations show that the applied research method and PEMS apparatus (Portable Emission Measurement 
Table 10 Allowable European emission limits of harmful exhaust gases for passenger vehicles and light delivery vehicles with spark ignition engine and date of implementation (Lindqvist, 2012; Gołębiowski et al. 2013; Delphi-Worldwide Emissions Standards,
2017; Council Directive, 1991, 1993; Directive, 1994/12/WE; Directive, 1996/69/WE; Directive, 1998/69/WE; Directive, 2002a/ 80/WE; Regulation 2007/715/WE)

Passenger vehicles (category M1*)

\begin{tabular}{|c|c|c|c|c|c|c|c|}
\hline Euro & Date & $\begin{array}{l}\mathrm{CO} \\
\mathrm{g} / \mathrm{km}\end{array}$ & $\mathrm{HC}$ & $\mathrm{HC}+\mathrm{NO}_{\mathrm{x}}$ & $\mathrm{NO}_{\mathrm{x}}$ & $\mathrm{PM}$ & $\begin{array}{l}\mathrm{PN} \\
\# / \mathrm{km}\end{array}$ \\
\hline I & 1992 & $2.72(3.16)$ & - & $0.97(1,13)$ & - & - & \\
\hline II & 1996 & 2.20 & - & 0.5 & - & - & \\
\hline III & 2000 & 2.30 & 0.20 & - & 0.15 & - & \\
\hline IV & 2005 & 1.0 & 0.10 & - & 0.08 & - & \\
\hline V & $2009^{\mathrm{a}}$ & 1.0 & $0.10^{\mathrm{b}}$ & - & 0.06 & $0.005^{\mathrm{c}, \mathrm{d}}$ & \\
\hline VI & 2014 & 1.0 & $0.10^{\mathrm{b}}$ & - & 0.06 & $0.005^{\mathrm{c}, \mathrm{d}}$ & $6.0 \times 10^{11 \mathrm{c}, \mathrm{e}}$ \\
\hline \multicolumn{8}{|c|}{ Light delivery vehicles, class $\mathrm{I}, \leq 1305 \mathrm{~kg}$ (category N1) } \\
\hline I & 1994 & 2.72 & - & 0.97 & - & & \\
\hline II & 1998 & 2.2 & - & 0.50 & - & & \\
\hline III & 2000 & 2.3 & 0.20 & - & 0.15 & & \\
\hline IV & 2005 & 1.0 & 0.10 & - & 0.08 & & \\
\hline $\mathrm{V}$ & $2009^{\mathrm{a}}$ & 1.0 & $0.10^{\mathrm{b}}$ & - & 0.06 & $0.005^{\mathrm{c}, \mathrm{d}}$ & \\
\hline VI & 2014 & 1.0 & $0.10^{\mathrm{b}}$ & - & 0.06 & $0.005^{\mathrm{c}, \mathrm{d}}$ & $6.0 \times 10^{11 \mathrm{c}, \mathrm{e}}$ \\
\hline \multicolumn{8}{|c|}{ Light delivery vehicles, class II, $1305-1760$ kg (category N1) } \\
\hline I & 1994 & 5.17 & - & 1.40 & - & - & \\
\hline II & 1998 & 4.0 & - & 0.65 & - & - & \\
\hline III & 2001 & 4.17 & 0.25 & - & 0.18 & - & \\
\hline IV & 2006 & 1.81 & 0.13 & - & 0.10 & - & \\
\hline $\mathrm{V}$ & $2010^{\mathrm{g}}$ & 1.81 & $0.13^{\mathrm{h}}$ & - & 0.075 & $0.005^{\mathrm{c}, \mathrm{d}}$ & \\
\hline VI & 2015 & 1.81 & $0.13^{\mathrm{h}}$ & - & 0.075 & $0.005^{\mathrm{c}, \mathrm{d}}$ & $6.0 \times 10^{11 \mathrm{c}, \mathrm{e}}$ \\
\hline \multicolumn{8}{|c|}{ Light delivery vehicles, class III, > 1760 kg (category N1) } \\
\hline I & 1994 & 6.90 & - & 1.70 & - & - & - \\
\hline II & 1998 & 5.0 & - & 0.80 & - & - & - \\
\hline III & 2001 & 5.22 & 0.29 & - & 0.21 & - & - \\
\hline IV & 2006 & 2.27 & 0.16 & - & 0.11 & - & - \\
\hline $\mathrm{V}$ & $2010^{\mathrm{g}}$ & 2.27 & $0.16^{\mathrm{h}}$ & - & 0.082 & $0.005^{\mathrm{c}, \mathrm{d}}$ & - \\
\hline VI & 2015 & 2.27 & $0.16^{\mathrm{h}}$ & - & 0.082 & $0.005^{\mathrm{c}, \mathrm{d}}$ & $6.0 \times 10^{11 \mathrm{c}, \mathrm{e}}$ \\
\hline \multicolumn{8}{|c|}{ Light delivery vehicles (category N2) } \\
\hline $\mathrm{V}$ & $2010^{\mathrm{g}}$ & 2.27 & $0.16^{\mathrm{h}}$ & - & 0.082 & $0.005^{\mathrm{c}, \mathrm{d}}$ & - \\
\hline VI & 2015 & 2.27 & $0.16^{\mathrm{h}}$ & - & 0.082 & $0.005^{\mathrm{c}, \mathrm{d}}$ & $6.0 \times 10^{11 \mathrm{c}, \mathrm{e}}$ \\
\hline
\end{tabular}

* During Euro 1.4 stages, passenger vehicles $>2500 \mathrm{~kg}$ have been homologated as vehicles of category $\mathrm{N}_{1}$

a 2011 for all models

${ }^{\mathrm{b}} \mathrm{NMHC}=0.068 \mathrm{~g} / \mathrm{km}$

${ }^{\mathrm{c}}$ Applicable only to vehicles using DI engines

${ }^{\mathrm{d}} 0.0045 \mathrm{~g} / \mathrm{km}$ using the PMP measurement procedure

${ }^{\mathrm{e}} 6.0 \times 10^{12} 1 / \mathrm{km}$ within first 3 years from Euro 6 effective dates

${ }^{\mathrm{f}} \mathrm{NMHC}=0.090 \mathrm{~g} / \mathrm{km}$

g 2012.01 for all models

${ }^{\mathrm{h}} \mathrm{NMHC}=0.108 \mathrm{~g} / \mathrm{km}$

System) should be implemented into the homologation procedure (Lijewski et al. 2017). The fundamental advantage of such tests is the coverage of all actual service conditions and aspects of combustion engine, which is hardly reproducible under laboratory conditions during tests performed on engine test beds.

The actual state of regulations in Europe in scope of the emission investigations of toxic compounds of exhaust gases 
Fig. 1 The European tendency of decreasing the emission limits of harmful exhaust gases for passenger vehicles and light delivery vehicles with spark ignition engine

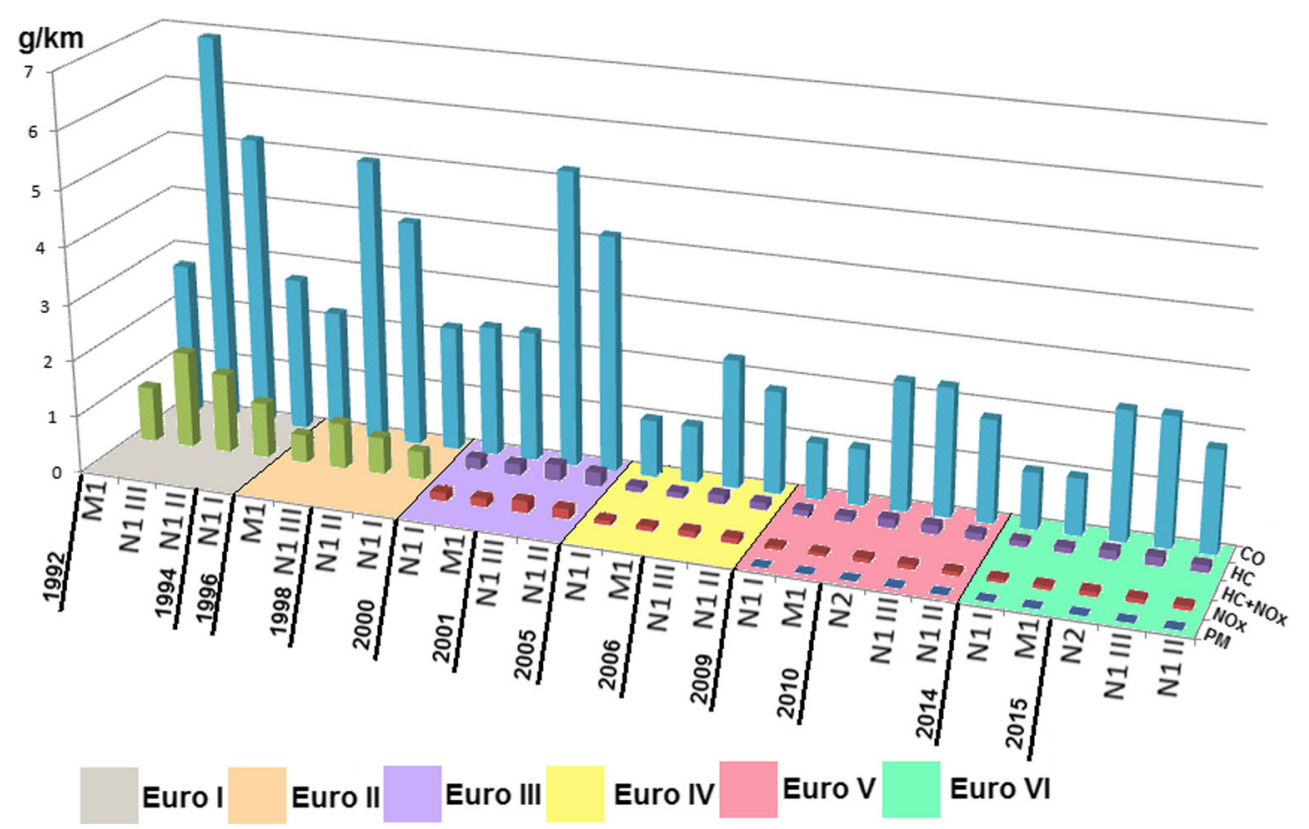

do not impose any obligations (apart from homologation tests) of control examinations of machine exhaust gas emission for producers and users of these machines. In spite of large efforts on the design and production phase, the exhaust gases emission of the engine can be highly increased during machine service due to wear or damage of engine elements. Therefore, it is well motivated to implement control procedures which will allow to detect the increased emission of the exhaust gases of the operating engine. This requires the elaboration of research methodology and implementation of proper regulations. Additionally, in case of non-road vehicles the engine and its elements are often exposed to failures due to specific service conditions. A lack of control procedures for vehicles is the reason of uncontrolled emission of toxic compounds from engines (Merkisz et al. 2010).

The regulations implemented by the European Parliament play a decisive role during the elaboration of progressive policy in the field of environment which will be applied to fight against the air pollution in Europe. The regulations and research methods on air pollution restrictions for engines should be resistant to such situations as in case of discrepancy between the real emissions and test emissions of the vehicles with diesel engines which satisfy the emission standard Euro 6. The example of such situation is the application of software to falsify the test results of $\mathrm{NO}_{\mathrm{x}}$ emission in the vehicles of the Volkswagen Group (Ohliger 2017).

\section{The analysis of the European homologation directives}

Homologation rules for combustion engines used in road applications have been implemented in 1990s. Nowadays, the regulations relating to the emission of this group of engines
Fig. 2 Implementation and revision of the European standards of the emission limits of toxic compounds in exhaust gases for spark ignition engines: passenger vehicles Euro*, goods vehicles Euro**, non-road mobile machinery Stage

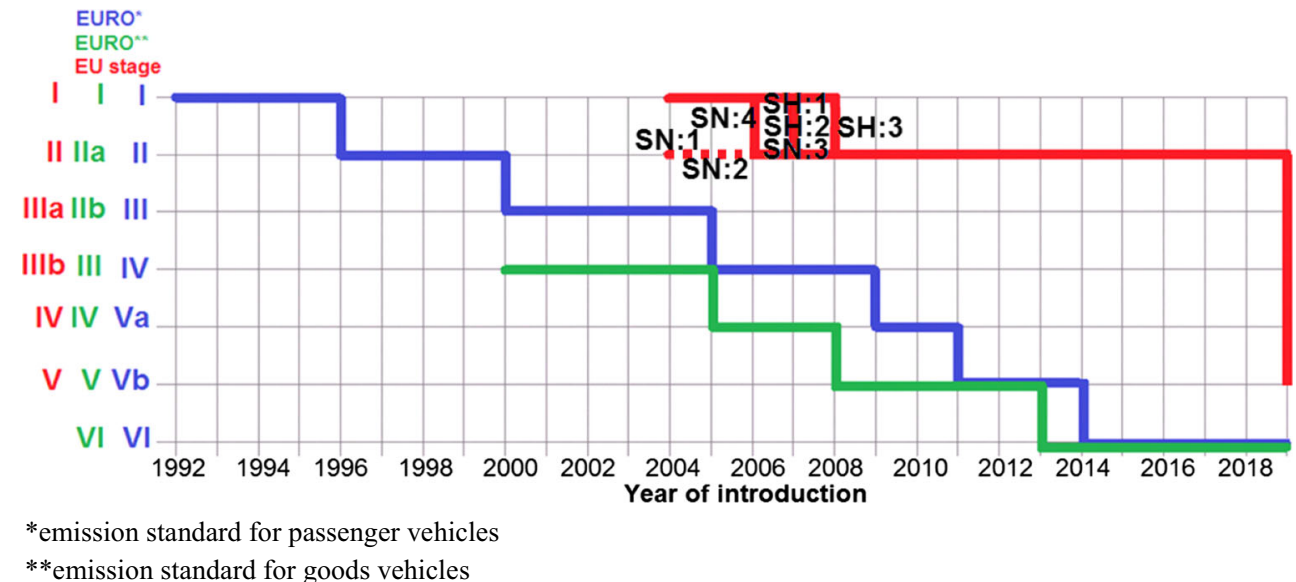


Fig. 3 Allowable emission limits of carbon monoxide $\mathrm{CO}$ in exhaust gases of spark ignition engines formulated in standards Euro and Stage

Fig. 4 Allowable emission limits of harmful compounds in exhaust gases of spark ignition engines formulated in standards Euro and Stage
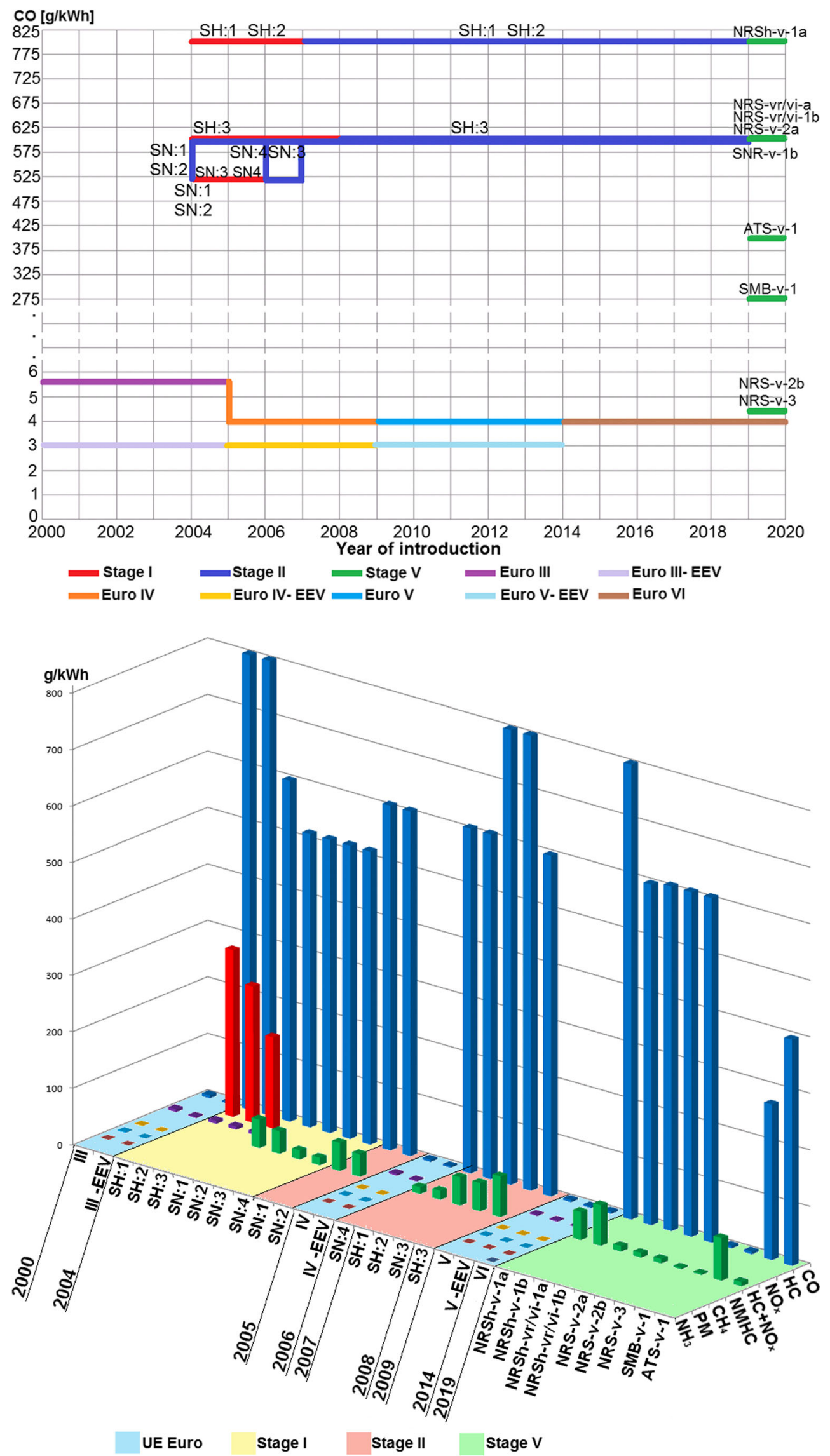
Table 11 Allowable European emission limits of toxic compounds in exhaust gases for passenger and goods vehicles with the allowable weight higher than $2610 \mathrm{~kg}$ and busses with total weight higher than $5 \mathrm{t}$ and delivery trucks with total weight higher than $12 \mathrm{t}$ regardless of their rated mass and equipped with spark ignition engine and date of implementation (Delphi-Worldwide Emissions Standards, 2017; Gołębiowski et al. 2013; Council Directive, 1991, 1993; Directive, 1994/12/WE; Directive, 199669/WE; Directive, 1998/69/WE; Directive, 2002a/80/WE; Regulation 2007/715/WE)

\begin{tabular}{|c|c|c|c|c|c|c|c|}
\hline EURO & Date & $\begin{array}{l}\text { Carbon } \\
\text { monoxide } \\
(\mathrm{CO})\end{array}$ & $\begin{array}{l}\text { Ammonia } \\
\left(\mathrm{NH}_{3}\right)\end{array}$ & $\begin{array}{l}\text { Nitrogen } \\
\text { oxides } \\
\left(\mathrm{NO}_{\mathrm{x}}\right)\end{array}$ & $\begin{array}{l}\text { Non-metallic } \\
\text { hydrocarbons } \\
\text { (NMHC) }\end{array}$ & $\begin{array}{l}\text { Methane } \\
\left(\mathrm{CH}_{4}\right)^{2}\end{array}$ & $\begin{array}{l}\text { Solid } \\
\text { particles } \\
(\mathrm{PM})\end{array}$ \\
\hline & & \multicolumn{6}{|l|}{$(\mathrm{g} / \mathrm{kWh})$} \\
\hline III & 2000 & 5.45 & - & 5.0 & 0.78 & 1.6 & $0.16 / 0.21^{1,3}$ \\
\hline III-EEV & 2000 & 3.0 & - & 2.0 & 0.4 & 0.65 & $0.02^{3}$ \\
\hline IV & 2005 & 4.0 & - & 3.5 & 0.55 & 1.1 & $0.03^{3}$ \\
\hline IV-EEV & 2005 & 3.0 & - & 2.0 & 0.4 & 0.65 & $0.02^{3}$ \\
\hline V & 2009 & 4.0 & - & 2.0 & 0.55 & 1.1 & $0.03^{3}$ \\
\hline V-EEV & 2009 & 3.0 & - & 2.0 & 0.4 & 0.65 & $0.02^{3}$ \\
\hline VI & 2014 & 4.0 & 0.01 & 0.46 & 0.5 & 0.5 & 0.01 \\
\hline
\end{tabular}

${ }^{1}$ For engines with engine cubic capacity below $0.75 \mathrm{dm}^{3}$ for one cylinder and the power rating $>3000 \mathrm{~min}^{-1}$

${ }^{2}$ In scope of standards Euro 3-Euro 5, this limit is related with the engines which are supplied with natural gas (NG), but in scope of standard Euro 6 this limit is related with spark ignition engines

${ }^{3}$ In scope of standards Euro 3-Euro 5, this limit is not related with the engines which are supplied with gas

are more rigorous than for the engines applied in non-road mobile machinery. This situation has an impact on design and construction of the applied supply and control systems for combustion engines. Non-road mobile machines are propelled mainly with petrol or diesel fuel. Apart from the abovementioned fuels, the manufacturers of leading makes introduce into service the engines which are supplied with alternative fuels e.g., LPG, CNG, kerosene, or biofuels. The solutions of the emission restriction for these engines are usually taken from the engines for road vehicles with few or several years delay.

The emission limits of toxic compounds in exhaust gases of Euro I-VI in Europe for spark ignition engines applied in passenger vehicles are measured in units $(\mathrm{g} / \mathrm{km})$ which does not allow to compare the implemented emission limits for non-road mobile machinery. The emission limits of passenger vehicles and light delivery vehicles classified as M1, N1, and classes I, II, III, and N2 are characterized with the most rigorous standards of exhaust gases emission (Table 11). Table 10 and Fig. 1 present a comparison of the European emission limits for passenger vehicles with up to eight seats excluding the driver's seat (M1) and for goods vehicles with maximal load capacity lower than 3.5 tons $(\mathrm{N} 1)$ and higher than 3.5 tones, but which does not exceed 12 tons (N2). The emission limits for passenger vehicles decrease with increasing the class or category which depends on the allowable vehicle weight.

The allowable European emission limits of harmful exhaust gases for passenger vehicles and goods vehicles with the allowable vehicle mass higher than $2610 \mathrm{~kg}$ and busses with total mass higher than $5 \mathrm{t}$ and delivery trucks with total mass higher than $12 \mathrm{t}$ —irrespective of their rated masses - are measured in units $\mathrm{g} / \mathrm{kWh}$ (Table 9). The values of the emission limits measured in this unit allow for their comparison with the values of the emission limits for non-road mobile machinery (Figs. 2, 3, 4). The review of goods vehicles was restricted to the emission limits for spark ignition engines. Euro 1 and Euro 2 standards for such type of vehicles are not related to spark ignition engines. The presented emission limits in Table 1 are also obligatory for compression ignition engines during ETC test in transient conditions (Delphi-Worldwide Emissions Standards, 2017; Gołębiowski et al. 2013). Table 9 presents the allowable emission limits which are divided according to the standards, and it shows the emission limits for enhanced environmental friendly vehicles (EEV). The EEV standard extorts extremely low emission level of particulate pollutants which are serious hazard for health and quality of life (Table 11).

\section{Conclusions}

The main aim of this review is the presentation of the actual state of the art on the subject of the influence of the EU regulations on the global emission of contamination from nonroad machinery. Their impact on the air quality cannot be omitted during consideration and analysis of all pollutant factors. On the basis of detailed analysis of literature, the authors of this paper have concluded that currently available information on the influence of non-road machinery and other devices in households driven by liquid fuels is insufficient. A lack of analysis of the influence of these machines on the general 
level of contamination and a lack of the regulations will be the reason of climate warming and larger smog formation.

The directives related to the emission limits of harmful compounds in exhaust gases for non-road mobile machinery with spark ignition engine are more liberal than the directives related to passenger or goods vehicles. Some legal activities are made for tightening the regulations for this machinery, and homologation limits are implemented with a few years of delay in relation to road vehicles. The values of the emission limit of harmful compounds in exhaust gases for this machinery are still considerably higher than for road vehicles. This fact has an influence on construction and control processes of these engines. In group of these engines the fuel supply system is made in majority with the application of the carburetor. The control possibilities of this system are considerably limited and therefore just a few percentage of passenger vehicles produced in 1993 was equipped with this type of fuel supply system (Wendeker 1999). One should expect that the innovations from road vehicle engines will be implemented into the engines for propulsion of non-road mobile machinery. The leading manufacturers, who implement the innovations into this group of engines e.g. Kohler Engines, Briggs \& Stratton, Honda, Kawasaki, Subaru Robin, Yamaha (Briggs \& Stratton gasoline engines, 2017; Honda gasoline engines, 2017; Kawasaki gasoline engines, 2017, Kohler Power Group gasoline engines, 2017; Subaru Industrial Power Products gasoline engines, 2017; Yamaha gasoline engines, 2017), present the innovative solution of the engine with the control process which is based on the integrated injectionignition systems where the injection is done into the suction manifold. These systems are free from catalytic reactor and feedback in control process. Integrated electronic injectionignition systems are characterized with better control of fuel dosage in comparison with carburetors. However, these engines are in the minority on the market of offered engines due to the liberal emission rules for non-road mobile machinery. The standards for passenger vehicles are more rigorous, but due to the measured units, we cannot compare directly these ones with the standards for non-road mobile machinery. The standard for passenger vehicles is more and more liberal in relation to allowable weight of the vehicle. Only standards for goods vehicles are represented in the unit which allows for comparison, and their emission limits are more rigorous than for non-road mobile machinery.

In case of engines for hand-held devices, the emission limits of toxic compounds in exhaust gases are the most liberal, but the most important in these devices are compact construction, weight, and generated vibration. The manufactures of these devices: Makita, Stihl and Shindaiwa (Makita hybrid of two- and four-stroke engines, 2017; Shindaiwa hybrid of two- andfour-stroke engines, 2017; Stihl hybrid of two- and four-stroke engines, 2017) propose the innovative engines which are the hybrid of two- and four-stroke engines. These ones are characterized with the power increase, reduction of toxic compounds emission, and reduction of noise. The fuel supply system of this engine is still based on the carburetor.

It was shown that the legal requirements impose the level of innovation of construction of ignition-injection systems. The local level of pollutants emission depends on the level of innovation of applied systems - this fact has a special meaning in urban agglomerations. This situation will lead to searching for the emission limits of harmful compounds in exhaust gases in all branches of the industry-including propulsions of machines and devices for non-road working machines. However, the main stimulation for searching will be the implementation of more rigorous standards of the emission limits which will be close to the emission limits for road vehicles. To restrict the emission level, one should start the works on the implementation of operation control systems of road vehicle engines into non-road mobile machinery engines. The application of homologation standards and innovative solutions transferred from automotive vehicles will allow to restrict the global emission of harmful compounds in exhaust gases.

Open Access This article is distributed under the terms of the Creative Commons Attribution 4.0 International License (http:// creativecommons.org/licenses/by/4.0/), which permits unrestricted use, distribution, and reproduction in any medium, provided you give appropriate credit to the original author(s) and the source, provide a link to the Creative Commons license, and indicate if changes were made.

\section{References}

Avila A, Alarcon M (2003) Precipitation chemistry at a rural Mediterranean site: Between anthropogenic pollu-tion and natural emissions. J Geophys Res-Atmos 108(D9):4278

Badami M, Marzano M, Millo F, Nuccio P (1999) Comparison between direct and indirect fuel injection in an SI two-stroke engine, SAE, Techn Paper 1999-01-3311, doi: https://doi.org/10.4271/1999-013311

Badyd AJ, Grellier J, Dąbrowiecki P (2017) Ambient PM2.5 exposure and mortality due to lung cancer and cardiopulmonary diseases in Polish cities. Adv Exp Med Biol 944:9-17. https://doi.org/10.1007/ 5584_2016_55

Bagayev I, Lochard J (2017) EU air pollution regulation: a breath of fresh air for Eastern European polluting industries? J Environ Econ Manag 83:145-163. https://doi.org/10.1016/j.jeem.2016.12.003

Baldauf R, Fortune C, Weinstein J, Wheeler M, Blanchard F (2006) Air contaminant exposures during the operation of lawn and garden equipment. J Exposure Sci Environ Epidemiol 16(4):362-370. https://doi.org/10.1038/sj.jes. 7500471

Battista G, Pagliaroli T, Mauri L, Basilicata C, De Lieto VR (2016) Assessment of the Air Pollution Level in the City of Rome (Italy). Sustainability 8(9):838. https://doi.org/10.3390/su8090838

Beelen R, Raaschou-Nielsen O, Stafoggia M, Jovanovic Andersen Z, Weinmayr G, Hoffmann B, Wolf K (2014) Effects of long-term exposure to air pollution on natural-cause mortality: an analysis of 22 European cohorts within the multicentre ESCAPE project. 
Lancet 383(9919):785-795. https://doi.org/10.1016/S01406736(13)62158-3

Beltman JB, Hendriks C, Tum M, Schaap M (2013) The impact of large scale biomass production on ozone air pollution in Europe. Atmos Environ 71:352-363. https://doi.org/10.1016/j.atmosenv.2013.02. 019

Bencs L, Horemans B, Buczyńska AJ, Van Grieken R (2017) Uneven distribution of inorganic pollutants in marine air originating from ocean-going ships. Environ Pollut 222:226-233. https://doi.org/10. 1016/j.envpol.2016.12.052

Bieda B (2011) Life cycle inventory of energy production in ArcelorMittal steel power plant Poland S.A. in Krakow, Poland. Int J Life Cycle Assess 16(6):503-511. https://doi.org/10.1007/ s11367-011-0292-8

Bollen J, Brink C (2014) Air pollution policy in Europe: quantifying the interaction with greenhouse gases and climate change policies. Energy Econ 46:202-215. https://doi.org/10.1016/j.eneco.2014.08. 028

Briggs \& Stratton gasoline engines (2017). https://www. briggsandstratton.com/na/en_us/products/engines.html. Ac-cessed January 2017

Brunel C, Levinson A (2016) Measuring the stringency of environmental regulations. Rev Environ Econ Policy 10(1):47-67. https://doi.org/ 10.1093/reep/rev019

Büchs M, Schnepf SV (2013) Who emits most? Associations between socio-economic factors and UK house-holds' home energy, transport, indirect and total CO2 emissions. Ecol Econ 90:114-123. https://doi.org/10.1016/j.ecolecon.2013.03.007

Byeong-Jae L, Bumseok K, Kyuhong L (2014) Air pollution exposure and cardiovascular disease. Toxicol Res 30(2):71-75

Cordell RL, Mazet M, Dechoux C, Hama SML, Staelens J, Hofman J, Stroobants C, Roekens E, Kos GPA, Wei-jers EP, Furmau KFA, Panteliadis P, Delaunay T, Wyche KP, Monks PS (2016) Evaluation of biomass burning across North West Europe and its impact on air quality. Atmos Environ 141:276-286. https://doi.org/ 10.1016/j.atmosenv.2016.06.065

Council Directive (1991) 91/441/EEC of 26 June 1991 amending Directive 70/220/EEC on the approximation of the laws of the Member States relating to measures to be taken against air pollution by emissions from motor vehi-cles

Council Directive (1993) 93/59/EEC of 28 June 1993 amending Directive 70/220/EEC on the approximation of the laws of the Member States relating to measures to be taken against air pollution by emissions from motor vehicles

Creutzig F, McGlynn E, Minx J, Edenhofer O (2011) Climate policies for road transport revisited (I): evaluation of the current framework. Energy Policy 39(5):2396-2406. https://doi.org/10.1016/j.enpol. 2011.01.062

Cruz C, Montenon A (2016) Implementation and impacts of low emission zones on freight activities in Europe: local schemes versus national schemes. Trans Res Procedia 12:544-556. https://doi.org/ 10.1016/j.trpro.2016.02.010

Czerwinski J, Kurzwart M, Mayer A, Comte P (2014) Particle emissions of modern handheld machines. SAE Techn Paper. https://doi.org/10. 4271/2014-32-0036

Delphi-Worldwide Emissions Standards, Heavy Duty and Off-Highway Vehicles. http://delphi.com/docs/default-source/worldwideemissions-standards/delphi-worldwide-emissions-standards-heavyduty-off-highway-15-16.pdf. Accessed January 2017

DieselNet- Emission Standards (2017). https://www.dieselnet.com/ standards/eu/nonroad_si.php. Accessed January 2017

Dimou V, Anezakis V, Demertzis K, Iliadis LS (2017) Comparative analysis of exhaust emissions caused by chainsaws with soft computing and statistical approaches. Springer, International Journal of Environmental Science and Technology, pp 3-14, ISSN 1735 1472. https://doi.org/10.1007/s13762-017-1555-0
Directive (1994) 94/12/WE of the European Parliament and the Council of 23 March 1994. Relating to measures to be taken against air pollution by emissions from motor vehicles and amending Directive 70/220/EEC

Directive (1996) 96/69/WE of the European Parliament and of the Council of 8 October 1996. Amending Directive 70/220/EEC on the approximation of the laws of the Member States relating to measures to be taken against air pollution by emissions from motor vehicles

Directive (1997) 97/68/WE of the European Parliament and of the Council of 16 December 1997. On the approximation of the laws of the Member States relating to measures against the emission of gaseous and particulate pollutants from internal combustion engines mobile machinery non-road

Directive (1998) 98/69/WE of the European Parliament and of the Council of 13 October 1998. Relating to measures to be taken against air pollution by emissions from motor vehicles and amending Council Directive 70/220/EWG

Directive 2001/63/WE of the European Parliament and of the Council of 17 August 2001. Adapting to technical progress Directive 97/68/ WE on the approximation of the laws of the Member States relating to measures against the emission of gaseous and particulate pollutants from internal combustion engines to be installed in mobile machinery non- the roads

Directive 2002a/80/WE of the European Parliament and of the Council of 3 October 2002. Adapting to technical progress, Council Directive $70 / 220 / E W G$ relating to measures to be taken against air pollution by emissions from motor vehicles

Directive 2002b/88 /WE of the European Parliament and of the Council of 9 December 2002. Amending Directive 97/68/WE on the approximation of the laws of the Member States relating to measures against the emission of gaseous and particulate pollutants from internal combustion engines to be installed in mobile machinery nonthe roads

Directive 2004/26/WE of the European Parliament and of the Council of 29 April 2004. Amending Directive 97/68/WE on the approximation of the laws of the Member States relating to measures against the emission of gaseous and particulate pollutants from internal combustion engines to be installed in mobile machinery non- the roads

Directive 2005/13/EC of the European Parliament and of the Council of 21 February 2005. Amending Directive 2000/25/EC of the council concerning the emission of gaseous and particulate pollutants by engines intended to power agricultural or forestry tractors, and amending Annex I to Directive 2003/37/EC of the European Parlia-ment and of the Council concerning the type-approval of agricultural or forestry tractors

Directive 2010a/22/EC of the European Parliament and of the Council of March 2010. Amending Directive 80/720/EEC, 86/298/EEC, 86/ 415/EEC and 87/402/EEC and Directives 2000/25/EC and 2003/37/EC of the European Parliament and of the Council relating to the type-approval of agricultural or forestry tractors

Directive 2010b/26/UE of the European Parliament and of the Council of 31 March 2010. Amending Directive 97/68/WE on the approximation of the laws of the Member States relating to measures against the emission of gaseous and particulate pollutants from internal combustion engines to be installed in mobile machinery non- the roads

Directive 2011/88/UE of the European Parliament and of the Council of 16 November 2011. Amending Di-rective 97/68/WE on the approximation of the laws of the Member States relating to measures against the emis-sion of gaseous and particulate pollutants from internal combustion engines to be installed in mobile machinery non- the roads

Directive 2012/46/UE of the European Parliament and of the Council of 6 December 2012. Amending Directive 97/68/WE on the 
approximation of the laws of the Member States relating to measures against the emission of gaseous and particulate pollutants from internal combustion engines to be installed in mobile machinery nonthe roads

Docker DW (2001) Epidemiologic evidence of cardiovascular effects of particulate air pollution. Environ Health Perspect 109:483-486

Dulcea D, Ionel I (2015) NOx emission reduction from Romania power plants - still an actual necessity. J Environ Protect Ecol 16(4):12371247

Ederington J, Levinson A, Minier J (2005) Footloose and pollution-free. Rev Econ Stat 87(1):92-99. https://doi.org/10.1162/ 0034653053327658

Fugiel A, Burchart-Korol D, Czaplicka-Kolarz K, Smoliński A (2017) Environmental impact and damage categories caused by air pollution emissions from mining and quarrying sectors of European countries. J Clean Prod 143:159-168. https://doi.org/10.1016/j. jclepro.2016.12.136

Gołębiowski P, Jachimowski R, Lewczuk K, Szczepan E, Wasiak M (2013) Legal conditions of proecological transport system development. Oficyna Wydawnicza Politechniki Warszawskiej, Prace Naukowe Politechniki Warszawskiej. Transport, z. 97, p. 135-145

Guerreiro CBB, Foltescu V, de Leeuw F (2014) Air quality status and trends in Europe. Atmos Environ 98:376-384

Heck RM, Farrauto RJ (2001) Automobile exhaust catalysts. Appl Catal A Gen 221(1-2):443-457. https://doi.org/10.1016/S0926-860X(01) 00818-3

Hoek G, Krishnan RM, Beelen R, Peters A, Ostro B, Brunekreef B, Kaufman JD (2013) Long-term air pollution exposure and cardiorespiratory mortality: a review. Environ Health 12(1):12-43

Honda gasoline engines (2017). http://engines.honda.com/models/. Accessed January 2017

Hooper B, Parker R, Todoroki C (2017) Exploring chainsaw operator occupational exposure to carbon monoxide in forestry. J Occup Environ Hyg 14(1):D1-D12. https://doi.org/10.1080/15459624. 2016.1229483

Hulskotte JHJ, Roskam GD, Denier van der Gon HAC (2014) Elemental composition of current automotive braking materials and derived air emission factors. Atmos Environ 99:436-445. https://doi.org/10. 1016/j.atmosenv.2014.10.007

ISO 8168-4 (1996) Aerospace - corrosion- and heat-resisting steel bolts with strength classification $1100 \mathrm{MPa}$ and $\mathrm{MJ}$ threads - procurement specification

ISO 8178-1 (2017) Reciprocating internal combustion engines. Exhaust emission measurement. Part 1: Test-bed measurement systems of gaseous and particulate emissions

ISO 8178-10 (2002) Reciprocating internal combustion engines Exhaust emission measurement Part 10: Test cycles and test procedures for field measurement of exhaust gas smoke emissions from compression ignition engines operating under transient conditions

ISO 8178-11 (2006) Reciprocating internal combustion engines Exhaust emission measurement Part 11: Test-bed measurement of gaseous and particulate exhaust emissions from engines used in nonroad mobile machinery under transient test conditions

ISO 8178-2 (2008) Reciprocating internal combustion engines Exhaust emission measurement Part 2: Measure-ment of gaseous and particulate exhaust emissions under field conditions

ISO 8178-3 (1994) Reciprocating internal combustion engines Exhaust emission measurement Part 3: Defini-tions and methods of measurement of exhaust gas smoke under steady-state conditions

ISO 8178-4 (2017) Reciprocating internal combustion engines Exhaust emission measurement Part 4: Steady-state and transient test cycles for different engine applications

ISO 8178-5 (2015) Reciprocating internal combustion engines Exhaust emission measurement Part 5: Test fuels

ISO 8178-6 (2000) Reciprocating internal combustion engines Exhaust emission measurement Part 6: Report of measuring results and test
ISO 8178-7 (2015) Reciprocating internal combustion engines Exhaust emission measurement Part 7: Engine family determination

ISO 8178-8 (2015) Reciprocating internal combustion engines Exhaust emission measurement Part 8: Engine group determination

ISO 8178-9 (2012) Reciprocating internal combustion engines Exhaust emission measurement Part 9: Test cy-cles and test procedures for test bed measurement of exhaust gas smoke emissions from compression ignition engines operating under transient conditions

Ivers-Tiffée E, Härdtla HK, Meneskloua W, Riegelb J (2001) Principles of solid state oxygen sensors for lean combustion gas control. Electrochim Acta 47(5):807-814. https://doi.org/10.1016/S00134686(01)00761-7

Jaś-Nowopolska M (2014) Selected activities leading to minimize the car's exhaust emissions. Przegląd Prawa Ochrony Środowiska p. 201-218, DOI: https://doi.org/10.12775/PPOS.2014.008

Jentz RR, Peters MW, DeZelia AI, Dudar AM (3.6.2014) Method and system for fuel vapor control. Ford Global Technologies, Llc, Numer publikacji US8739766 B2, Numer zgłoszenia US 13/198, 299, Data publikacji 3,Cze 2014, Data zgłoszenia 4 Sie 2011

Journal of Laws from 2014, No. 0, item 588 (original title in Polish: Dz. U. z 2014 r. Nr 0, poz. 588) - Regulation of the Ministers of Economy On 30 April 2014. On the detailed requirements for internal combustion engines to reduce the emission of gaseous and particulate emissions for these engines

Kawasaki gasoline engines (2017). http://www.kawasakienginesusa. com/engines. Accessed January 2017

Klæboe R, Amundsen AH, Fyhri A (2008) Annoyance from vehicular air pollution: a comparison of European exposure-response relationships. Atmos Environ 42(33):7689-7694. https://doi.org/10.1016/j. atmosenv.2008.04.049

Kohler Power Group gasoline engines (2017). https://power.kohler.com/ na-en/engines/engines. Accessed January 2017

Koudis GS, SJ H, Majumdar A, Jones R, Stettler MEJ (2017) Airport emissions reductions from reduced thrust takeoff operations. Transp Res Part D: Transp Environ 52:15-28. https://doi.org/10.1016/j.trd. 2017.02.004

Lackovičová A, Guttová A, Bačkor M, Pišút P, Pišút I (2013) Response of Evernia prunastri to urban environ-mental conditions in Central Europe after the decrease of air pollution. Lichenologist 45(1):89 100. https://doi.org/10.1017/S002428291200062X

Lacressonnière G, Watson L, Gauss M, Engardt M, Andersson C, Beekmann M, Colette A, Foret G, Josse B, Marécal V, Nyiri A, Siour G, Sobolowski S, Vautard R (2017) Particulate matter air pollution in Europe in a $+2{ }^{\circ} \mathrm{C}$ warming world. Atmos Environ 154:129-140. https://doi.org/10.1016/j.atmosenv.2017.01.037

Le Boennec R, Salladarré F (2017) The impact of air pollution and noise on the real estate market. The case of the 2013 European Green Capital: Nantes, France. Ecol Econ 138:82-89. https://doi.org/10. 1016/j.ecolecon.2017.03.030

Levinson A, Taylor MS (2008) Unmasking the pollution haven effect. Int Econ Rev 49(1):223-254. https://doi.org/10.1111/j.1468-2354. 2008.00478.x

Lichter A, Pestel N, Sommer E (2017) Productivity effects of air pollution: evidence from professional soccer. Labour Econ 48:54-66

Lijewski P (2015) Exhaust emissions measurements from non-road vehicles. J Mech Trans Engineering 67(1):37-46

Lijewski P, Fuć P, Dobrzyński M, Markiewicz F (2017) Exhaust emissions from small engines in handheld devices. MATEC Web of Conferences 118, 00016, VII International Congress on Combustion Engines

Lindqvist K (2012) Emission standards for light and heavy road vehicles. AirClim Factsheet No: 25 http://www.airclim.org/sites/default/files/ documents/Factsheet-emission-standards.pdf

Liora N, Poupkou A, Giannaros MT, Kakosimos KE, Stein O, Melas D (2016) Impacts of natural emission sources on particle pollution 
levels in Europe. Atmos Environ 137:171-185. https://oi.org/10. 1016/j.atmosenv.2016.04.040

Liu S, Han W, Zeng J, Wang J (2016) Analysis of combustion and emission characteristics of electronic controlled low pressure injected small gasoline engine. Trans Chin Soc Agric Eng 32(18):92-97. https://doi.org/10.11975/j.issn.1002-6819.2016.18.012

Makita hybrid of two- and four-stroke engines (2017). https://www. makita.co.nz/technology/MM4.lsd. Accessed Janu-ary 2017

Masiol M, Harrison RM (2014) Aircraft engine exhaust emissions and other airport-related contributions to ambient air pollution: a review. Atmos Environ 95:409-455. https://doi.org/10.1016/j.atmosenv. 2014.05.070

Ménil F, Coillard V, Lucata C (2000) Critical review of nitrogen monoxide sensors for exhaust gases of lean burn engines. Sensors Actuators B Chem 67(1-2):1-23. https://doi.org/10.1016/S09254005(00)00401-9

Merkisz J, Walasik S (2006) Comments on the emission standards for offroad engines. The archives of automotive. Engineering 1:41-51

Merkisz J, Lijewski P, Walasik S (2010) The analysis of non-road vehicle engine operating conditions in terms of emission regulations. Maintenance and reliability, $\mathrm{nr} 1 / 2010$, p. $42-48$

Merkisz J, Lijewski P, Pielecha J (2016) PEMS-based investigations into exhaust emissions from non-road and rail vehicles. Comb Eng 166(3):46-53. https://doi.org/10.19206/CE-2016-339

Moos R (2005) A brief overview on automotive exhaust gas sensors based on electroceramics. Int J Appl Ceram Technol 2(5):401413. https://doi.org/10.1111/j.1744-7402.2005.02041.x

Nam K-M, Waugh CJ, Paltsev S, Reilly JM, Karplus VJ (2014) Synergy between pollution and carbon emissions control: comparing China and the United States. Energy Econ 46:186-201. https://doi.org/10. 1016/j.eneco.2014.08.013

Nieuwenhuijsen MJ (2016) Urban and transport planning, environmental exposures and health-new concepts, methods and tools to improve health in cities. Environ Health: A Global Access Sci Source 15:38. https://doi.org/10.1186/s12940-016-0108-1

Oberdorster G (2001) Pulmonary effects of inhaled ultrafine particles. Int Arch Occup Environ Health 74:1-8

Ohliger T (2017) Air pollution and noise. Factsheet on the European Union http://www.europarl.europa.eu/atyourservice/pl/displayFtu. $\mathrm{html}$ ?ftuId=FTU 5.4.5.html

Pascal M, Corso M, Chanel O, Declercq C, Badaloni C, Cesaroni G, Henschel S, Meister K, Haluza D, Martin-Olmedo P, Medina S, on behalf of the Aphekom group (2013) Assessing the public health impacts of urban air pollution in 25 European cities: results of the Aphekom project. Sci Total Environ 449(p):390-400. https://doi. org/10.1016/j.scitotenv.2013.01.077

Pereira Filho MA, LAA P, Arbex FF, Arbex M, Conceição GM, Santos UP, Lopes AC, PHN S, ALF B, Cendon S (2008) Effect of air pollution on diabetes and cardiovascular diseases in São Paulo, Brazil. Braz J Med Biol Res 41(6):526-532. https://doi.org/10. 1590/S0100-879X2008005000020

Pyka I, Wierzchowski K (2016) Estimated mercury emissions from coal combustion in the households sector in Poland. J Sustain Min 15(2): 66-72

Rafaj P, Amann M, Siri GJ (2014) Factorization of air pollutant emissions: projections versus observed trends in Europe. Sci Total Environ 494-495:272-282

Ramamoorthy R, Dutta PK, Akbar SA (2003) Oxygen sensors: materials, methods, designs and applications. J Mater Sci 38(21):4271-4282. https://doi.org/10.1023/A:1026370729205

Regulation 2007/715/WE of the European Parliament and of the Council of 20 June 2007. On type approval of motor vehicles with respect to emissions from light passenger and commercial vehicles (Euro 5 and Euro 6) and on access to information on vehicle repair and maintenance
Regulation 2016/1628/UE of the European Parliament and of the Council of 14 September 2016. On require-ments for emission limit values of gaseous and particulate pollutants and type-approval with respect to internal combustion engines for mobile machines non-road, amending Regulations (EU) No 1024/2012 and (EU) No 167/2013 and amending and repealing Directive 97/68/WE

Regulation (EC) No. 443/2009 of the European Parliament and of the Council of 23 April 2009 setting emission performance standards for new passenger cars as part of the Community's integrated approach to reduce $\mathrm{CO} 2$ emissions from light-duty vehicles

Riegel J, Neumann H, Wiedenmann H-M (2002) Exhaust gas sensors for automotive emission control. Solid State Ionics 152-153:783-800

Rodriguez MC, Dupont-Courtade L, Oueslati W (2016) Air pollution and urban structure linkages: evidence from European cities. Renew Sust Energ Rev 53:1-9. https://doi.org/10.1016/j.rser.2015.07.190

Rückerl R, Schneider A, Breitner S, Cyrys J, Peters A (2011) Health effects of particulate air pollution - a review of epidemiological evidence. Inhal Toxicol 23:555-592

Sack CS, Kaufman JD (2016) Air pollution levels and children's lung health. How low do we need to go? Am J Respir Crit Care Med 193(8):819-820. https://doi.org/10.1164/rccm.201512-2436ED

Sanidas E, Papadopoulos, GH, Velliou M, Tsioufis K, Barbetseas J, Papademetriou V (2017) Air pollution and arterial hypertension. A new risk factor is in the air. J Am Soc Hyperten (article in press) p. $1-7$

Sathish M, Loganathan VN (2017) Design of secondary air injection system in lower cc engines - a review. Int Res J Eng Technol 4(9): 1329-1333

Shindaiwa hybrid of two- and four-stroke engines (2017). http://www. shindaiwa-tools.co.uk/index.php?id=141. Ac-cessed January 2017

Squizzato S, Cazzaro M, Innocente E, Visin F, Hopke PK, Rampazzo G (2017) Urban air quality in a mid-size city-PM2.5 composition, sources and identification of impact areas: from local to long range contributions. Atmos Res 186:51-62. https://doi.org/10.1016/j. atmosres.2016.11.011

Stihl hybrid of two- and four-stroke engines (2017). http:/www.stihl. com/4-mix-engine-lightweight-and-with-good-lugging-power.aspx. Accessed January 2017

Subaru Industrial Power Products gasoline engines. http://www. subarupower.com/products/\#generators. Ac-cessed January 2017

Szczepanek M (2009) Requirements of Polish law referring to the limitation of the toxic emission into the atmosphere. Sci J Marit Univ Szczecin 19(91):97-101

Tang G, Zhao P, Wang Y, Gao W, Chang M, Xin J, Li X, Wang Y (2017) Mortality and air pollution in Beijing: the long-term relationship. Atmos Environ 150:238-243. https://doi.org/10.1016/j.atmosenv. 2016.11.045

Twigg MV (2006) Rôles of catalytic oxidation in control of vehicle exhaust emissions. Catal Today 117(4):407-418. https://doi.org/10. 1016/j.cattod.2006.06.044

Twigg MV (2007) Progress and future challenges in controlling automotive exhaust gas emissions. Appl Catal B Environ 70(1-4):2-15. https://doi.org/10.1016/j.apcatb.2006.02.029

Ueda T (2015) Development of low pressure exhaust gas recirculation system for exhaust gas emission control of Mitsubishi UE diesel engine. Trans J JIME Vol. 50, No. 6

Vedal S (2002) Update on the health effects of outdoor air pollution. Clin Chest Med 23(4):763-775

Wales DJ, Grand J, Ting VP, Burke RD, Edler KJ, Bowen CR, Mintova S, Burrows AD (2015) Gas sensing using porous materials for automotive applications. Chem Soc Rev 44(13):4290-4321. https://doi. org $/ 10.1039 / \mathrm{C} 5 \mathrm{CS} 00040 \mathrm{H}$

Waluś KJ, Warguła $\measuredangle$, Krawiec P, Adamiec JM (2017) The impact of the modernization of the injection-ignition system on the parameters of motion of the motorcycle. Procedia Eng 177:393-398. https://doi. org/10.1016/j.proeng.2017.02.221 
Wang F, Li Z, Zhang K, Di B, Hu B (2016) An overview of non-road equipment emissions in China. Atmos Environ 132:283-289. https://doi.org/10.1016/j.atmosenv.2016.02.046

Warguła $Ł$, Waluś KJ (2014) Conceptual project of modernization of the ignition system and injection in a motorcycle Dnepr MT 11 - research of the object. Logistyka/ Instytut Logistyki i Magazynowania, 6/2014, p. 10883-10892. - CD-ROM 3

Wendeker M (1999) Control of ignition in a car engine. Lublin Scientific Society

WHO Regional Office for Europe and OECD (2015) WHO Regional Office for Europe, and OECD, 2015. Eco-nomic cost of the health impact of air pollution in Europe: clean air, health and wealth. Copenhagen

Yamaha gasoline engines. https://www.yamahamotorsports.com/multipurpose-engine. Accessed January 2017

Yang W, Omaye ST (2009) Air pollutants, oxidative stress and human health. Mutat Res Generic Toxicol Environ Mutagenesis 674:45-54

Yilmaz İ (2017) Emissions from passenger aircrafts at Kayseri Airport, Turkey. J Air Trans Manag 58:176-182. https://doi.org/10.1016/j. jairtraman.2016.11.001

Yu B, Kum S-M, Lee C-E, Lee S (2013) Effects of exhaust gas recirculation on the thermal efficiency and com-bustion characteristics for premixed combustion system. Energy 49:375-383. https://doi.org/ 10.1016/j.energy.2012.10.057

Zeng X-W, Vivian E, Mohammed KA, Jakhar S, Vaughn M, Huang J, Zelicoff A, Xaverius P, Bai Z, Lin S, Hao Y-T, Paul G, Morawska L, Wang S-Q, Qian Z, Dong G-H (2016) Long-term ambient air pollution and lung function impairment in Chinese children from a high air pollution range area: the Seven Northeastern Cities (SNEC) study. Atmos Environ 138:144-151. https://doi.org/10.1016/j. atmosenv.2016.05.003

Zhang F, Klimont Z, Streets DG, Huo H, He K (2006) Nitrogen model of PM sourced from human activities in China and emission inventory in 2001. Prog Nat Sci 16(2):223-231

Zhao F, Lai M-C, Harrington DL (1999) Automotive spark-ignited directinjection gasoline engines. Prog Energy Combust Sci 25(5):437562. https://doi.org/10.1016/S0360-1285(99)00004-0

Zijlema WL, Wolf K, Emeny R, Ladwing KH, Peters A, Kongsgård HK, Kvaløy K, Yli-Tuomi T, Partonen T, Lanki T, Eeftens M, de Hoogh K, Brunekreef B, BioSHaRE SRP, Rosmalen JGM (2016) Int J Hyg Environ Health 219(2):212-219

Zimmer A, Koch N (2017) Fuel consumption dynamics in Europe: tax reform implications for air pollution and carbon emissions. Transp Res A Policy Pract 106:22-50. https://doi.org/10.1016/j.tra.2017. 08.006 